\title{
Personhood and Rights in an African Tradition
}

\section{Motsamai Molefe}

To cite this article: Motsamai Molefe (2017): Personhood and Rights in an African Tradition, Politikon, DOI: 10.1080/02589346.2017.1339176

To link to this article: http://dx.doi.org/10.1080/02589346.2017.1339176

\section{Published online: 16 Jun 2017.}

Submit your article to this journal ๔

Q View related articles $₫$

View Crossmark data $\asymp$ 


\title{
Personhood and Rights in an African Tradition
}

\author{
Motsamai Molefe \\ Ethics Studies, University of KwaZulu Natal, Durban, South Africa
}

\begin{abstract}
It is generally accepted that the normative idea of personhood is central to African moral thought, but what has not been done in the literature is to explicate its relationship to the Western idea of rights. In this article, I investigate this relationship between rights and an African normative conception of personhood. My aim, ultimately, is to give us a cursory sense why duties engendered by rights and those by the idea of personhood will tend to clash. To facilitate a meaningful philosophical discussion, I locate this engagement in the context of a debate between Ifeanyi Menkiti and Kwame Gyekye about the nature of Afrocommunitarianism, whether it will ground rights as primary or secondary. I endorse Menkiti's stance that duties are primary and rights secondary; and, I also problematise moderate communitarianism for taking a Western stance by employing a naturalist approach to rights.
\end{abstract}

\section{Introduction}

What is the relationship between the normative idea of personhood in African moral thought and the idea of rights? The normative idea of personhood was first identified by Ifeanyi Menkiti, a Nigerian philosopher. It refers to agents who lead morally virtuous lives (Menkiti 1984, 2004). I ask this question because Menkiti $(1984,180)$ observes that rights in an African axiological system are ranked secondary to the primacy of our duties to the collective. Unfortunately, Menkiti never offered a philosophical argument to defend this position that departs from the global sway of rights.

The proposition that relegates rights to a secondary status in an Afro-communitarian system in favour of the priority of duties has been scathed for being 'excessive', 'unrestricted' and/or 'radical' view since it does not properly recognise the relevance and primacy of rights (Gyekye 1992, 103-104, 108). Other African scholars have also insisted on the primacy of rights in an African tradition (Wiredu 1996; Deng 2004; Metz 2011; Oyowe 2014).

In this article, I give moral-theoretical content to Menkiti's stance that duties take priority over rights in an African moral-political system. To do so, I invoke the idea of personhood since it is at the heart of an Afro-communitarian axiological system. The idea of personhood, I hope to demonstrate, entails a purely other-regarding morality of duties; it is these duties that take priority over rights. Rights are considered to be secondary because they will have a tendency to clash with the fundamental moral-social goal posited by a morality of duties of securing the well-being of all human beings entailed by this idea of personhood. 
What makes this project worth taking seriously is its attempt to give philosophical content to a position that has been thought to be obviously implausible in the literature: the idea that duties take priority over rights ${ }^{1}$ (Gyekye 1992, 1997; Matolino 2009; Famanikwa 2010). This article goes against the current of influence in terms of questioning the place that rights ought to occupy in African political thought: the idea that rights are universal and all that African scholars have to do is to domesticate them (Cobbah 1987; Ake 1987; Deng 2004).

My position as an African scholar born in a world that still bears features of colonisation and Western influence is that we need to proceed from a position of intellectual suspicion with regard to values born out of the Western enlightenment project (Maclntyre 2003), particularly when there are Western scholars who cast doubt on the ontological status of this very idea of rights ${ }^{2}$ (Maclntyre 2003) and more so when we are in the political space burdened with African people seeking African solution to African problems (Biko 2004). This intellectual suspicion is born out of a political objective to seek local axiological strategies for securing the human good without appeal to rights, particularly given that we are aware that rights are just 'one way' to secure a life of dignity and this way is reported to be 'foreign' to non-Western societies including Africa (Donnely 2009, 12, 1982a, 303).

In this article, I do not go as far as rejecting rights completely. Rather, I simply limit myself to giving philosophical content to Menkiti's idea that duties take priority over them. To make a case for the primacy of duties and the secondary status of rights in African moral thought, I proceed in the following fashion. I begin by revisiting Menkiti's analysis of an African notion of personhood. Here, I demonstrate that Menkiti employed three distinct notions of a 'person' and only one is crucial to his project: the idea that personhood is something that has to be achieved. Secondly, I proceed to roughly demonstrate that Gyekye's criticism and solution to ground rights employs a different notion of personhood from one used by Menkiti; he appeals to one that is dominant in a Western tradition. Finally, I conclude by demonstrating that the notion of personhood central to Menkiti's analysis entails a morality of duties to secure the well-being of all. The idea of personhood represents an African approach to secure a life of dignity.

\section{Revisiting Menkiti on 'personhood'}

Much of the confusion in a quest to articulating a plausible conception of Afro-communitarianism can be attributed to the ambiguity attending the notion of personhood in the literature (Metz 2013, 7; Molefe 2016). To make moral-theoretical progress in articulating Afro-communitarianism, we need to be clear about different notions of personhood. I identify three distinct notions of personhood in Menkiti's analysis. These are: (1) personhood as a claim about personal identity; (2) personhood as a claim about moral status and (3) personhood as a claim about human beings who are morally upright or virtuous.

It is unfortunate that Menkiti does not distinguish these distinct ideas of personhood the way I just did, rather he leaves it to the reader to pick them out. Menkiti $(1984,171$, author's emphasis) merely informs us that he is after 'a certain conception of the person found in African traditional thought'. This assertion does not quite help us to understand which one is central to his analysis. Below, I begin by teasing out these three distinct notions of a person. 
In Menkiti's analysis, I note the first notion of a person as one typical in Afrocommunitarian articulations of how individuals come to form personal identities. In this light, he notes:

... the African view of man denies that persons can be defined by focusing on this or that physical or psychological characteristic of the lone individual. Rather, man is defined by reference to the environing community. As John Mbiti notes, the African view of the person can be summed up in this statement: 'I am because we are, and since we are, therefore I am' $(1984,171)$.

It is important to note that here Menkiti is talking about an African view of a 'man' in context where he distinguishes it from Western notions of a person. It is safe to assume that he uses the notion of a 'man' interchangeably to that of a 'person'. This is hardly surprising because this is exactly how John Mbiti, whom he quotes, also uses these terms (1969, 108-109). Menkiti notes that a Western view defines a person in terms of some feature(s) intrinsic in a human being like consciousness, memory or rationality. Concomitantly, an African view defines a person by relying on the environing community. It is obvious that Menkiti is not interested here in giving a 'philosophical anthropological' account of a human person, that is, an account that specifies properties that constitute a human being, be they physical or spiritual (see, Kaphagawani 2004). I say so because an 'environing community' is not a ontological feature of a human being, rather it refers to external socio-cultural factors that are crucial in the process of becoming a human being in the sense of forming a personal identity.

What begins to emerge here is that one cannot become a normal functioning human being without being inserted in an 'environment' with other human beings; hence, the idea, 'I am because we are'. Personal identity here is understood primarily in terms of 'being-with-others' (Louw 2004; Menkiti 2004, 324). This position is further supported by Menkiti when he comments:

... as far as Africans are concerned, the reality of the communal world takes precedence over the reality of individual life histories ... it is by first knowing this community as a stubborn perduring fact of the psychophysical world that the individual also comes to know himself as a durable, more or less permanent, fact of this world ... What is more, the sense of self-identity which the individual comes to possess cannot be made sense of except by reference to these collective facts (1984, 172, author's emphasis).

Here, Menkiti becomes explicit about what he means by an idea of an environment. By 'environment' he has in mind what he refers to as the 'communal world' that a human being is born into and he also speaks of it as a world of 'collective facts'. So, Menkiti's talk of an environment refers to the whole gamut of a culture that serves as an incubator in the process of socialisation (humanisation) and also of forming personal identity. More explicitly he tells us that self-identity is possible only by reference to these collective (cultural) facts. In other words, Menkiti makes claims about socialisation and how individuals come to form their personal identities. And, in this process of identity formation, he insists that the community or social relationships are decisive.

So, the first sense of personhood refers to the fact that individuals in a communitarian context essentially require relationships to form personal identities. This is a metaphysical view that merely describes how human beings come to form their identities. 
The second notion of personhood is found when Menkiti invokes John Rawls in his discussion of personhood. Menkiti seems to think that Rawls is his ally in articulating a particular notion of a person that he considers salient in African thought. He notes 'John Rawls, of the Western-born philosophers, comes closest to a recognition of this importance of ethical sense in the definition of personhood' (Menkiti 1984, 178). Menkiti thinks Rawls' own normative notion of a person comes close to his own. I observe, however, that Rawls' notion of personhood is far removed from Menkiti's construction. Menkiti cites Rawls to clarify this notion:

Equal justice is owed to those who have the capacity to take part in and to act in accordance with the public understanding of the initial situation. One should observe that moral personality is here defined as a potentiality that is ordinarily realized in due course. It is this potentiality which brings the claims of justice into play ... The sufficient condition for equal justice [is] the capacity for moral personality. (178)

It is crucial to note that the notion of personhood employed by Rawls is essentially associated with 'equal justice'. In other words, the notion he has in mind is dependent on facts possessed by human beings in virtue of which their equality is recognised. Rawls refers to this feature possessed by human beings as a capacity to be party to a contract or what he refers to as an initial situation. Those who possess the relevant capacity are owed duties of justice. The very language of capacity implies that personhood here is conceived as a function of some feature intrinsic to a human being, and that this feature is possessed by all human beings; hence a talk of 'equal justice'. Beings who have a moral personality by possessing the relevant psychological properties count as persons insofar as they are moral patients.

Talk of personhood in this sense is usually referred to in a Western context as 'moral status' (Behrens 2013). The idea of 'moral status' has to do with an identification of some feature or capacity possessed by some entity in virtue of which it counts as a moral patient and as such deserving moral regard (Toscano 2011; Behrens 2013). This idea of personhood is a patient-centered one since it is concerned about what is due to some entity not for what it does or has done but merely because it has the relevant capacity or properties (Darwall 1977). ${ }^{3}$ In other words, put more simply, some being is worthy of respect merely for being the kind of a being it is, depending on what property is thought to be crucial, be it rationality, sentience or capacity for love (Metz 2012).

The last notion of personhood is also a moral notion except that it is an agent-centered one. To refer to some human being as a person, in this sense, it is to commend her moral conduct; it is to judge her as morally praiseworthy or morally standing out (Wiredu 2009). Those agents who successfully live according to norms of a society are considered persons and those who do not as non-persons (Gyekye 1997). What is granted here is a status that reflects one's moral achievement and what is denied is this kind of status, without making claims about one's biological status as a human being. The evaluation at play is at a moral level. It is for this reason that Menkiti $(1984,176)$ informs us that 'personhood is the sort of thing which has to be attained' and one who has it is 'marked by a widened maturity of ethical sense - an ethical maturity without which personhood is conceived as eluding one'. Menkiti also marries this idea to what he refers to as 'moral arrival' or 'triumph' and those who have triumphed he characterises them as having 'inbuilt excellencies' (Menkiti 1984, $173,2004,326)$. I understand this talk of personhood in terms of 'widened maturity', 'moral 
arrival' and 'inbuilt excellencies' to refer to human beings whose lives are characterised by moral virtue or sound characters (Behrens 2013).

Though both these two last notions of personhood are moral, they differ in significant ways. One is patient-centred and the other is agent-centred. In other words, moral status is concerned about the respect every human being should get merely because they are human; and, the agent-centred one refers to respect an agent earns relative to individual performance. On a patient-centred notion, respect tracks ontology; and, on the agentcentred one, it tracks performance. Since, the former tracks ontology that respect under considerations is invariable, all those who have the relevant ontology are to be respected in spite of their performance; and, on the latter, here respect is variable and varies relative to one's moral achievements. ${ }^{4}$

These are three distinct notions of personhood that I find in Menkiti's article on personhood, but Menkiti is ultimately after $a$ certain notion of personhood. I here submit that Menkiti is ultimately after the agent-centred notion of personhood, and there is convergence in the literature to support this view (Wiredu 1992, 2009; Dzobo 1992; Gyekye 1997; Ikuenobe 2006; Metz 2007, 2010; Behrens 2013; Molefe 2016).

To demonstrate this claim, I will draw heavily from one of the most influential African philosophers Kwasi Wiredu. In several instances, Wiredu comments on Menkiti's analysis on the notion of personhood. Wiredu comments rather approvingly on Menkiti; he refers to his analysis on personhood as 'an article of superlative beauty' $(2009,16)$. He observes that Menkiti was the first one to articulate this notion of personhood in the tradition, though it was already anticipated by anthropologists (Wiredu 2009). With specific reference to the 'debate' between Menkiti and Gyekye, Wiredu is unequivocal that he sides with Menkiti. In this regard, Wiredu avers:

One major point of doctrinal disagreement is, actually, between the two editors of this volume, namely, Gyekye and myself. Gyekye in chapter 5: 'Person and Community in Akan Thought' strongly disputes the view, advanced by a Nigerian philosopher Ifeanyi Menkiti, that personhood, as conceived in African thought, is not something one is born with but rather but an ideal one may or may not attain in life. I happen to have independently arrived at basically the same view as Menkiti .... $(1992,8)$

This editorial comment is crucial on the part of Wiredu. It appears in one of the most influential anthologies in the African philosophical tradition. In fact, it is in this very volume that Gyekye first criticised and accused Menkiti of articulating a view that represents radical communitarianism. Here, Wiredu endorses Menkiti's interpretation of personhood as essentially about a moral ideal truly befitting human life and this ideal is not achieved by every human being. African scholars also observe that normative personhood is 'germane', 'more dominant' and 'definitive' of African moral thought (lkuenobe 2006, 117; Wiredu 2009, 13; Masolo 2010, 135).

Finally, Menkiti himself offers evidence that he is after a normative notion of personhood. The reader will remember that when Menkiti introduced his 1984 article, he merely stated that he is after 'a certain conception of the person found in traditional thought'. But, we noted that this does not quite help us given that we have identified three distinct notions of a person in his article. The title of this article is Person and Community in African Traditional Thought. This title also does not quite help to clarify which notion of personhood is relevant. 
Menkiti restated his contribution on personhood in 2004. In this particular article, Menkiti is unequivocal about the notion of personhood he is after. The first cue is found in the title of the article which is On the Normative Conception of a Person. The article reads more or less the same as the 1984 contribution, except that here Menkiti clarifies that he is after an agentcentered notion. To this effect I cite one passage to demonstrate:

For married to the notion of person is the notion of moral arrival, a notion involving yardsticks and gradations, or, more simply, involving an expectation that certain ways of being or behaving in the world may be so off the mark as to raise important questions regarding the personstatus of their doers. (2004, 326, author's emphasis)

Here it is clear that this is a moral notion since it is married to moral arrival. And, I hope it is clear that this notion is agent-centred since it has to do with certain ways of being or conducting oneself in the world and it is concerned about the status of the doer. Also, Menkiti suggests that variability of this feature by using ideas of gradations, some may not be persons at all, and others may have some of it and others more of it. I proceed now to revisit Gyekye's criticism of Menkiti and his proposed solution.

\section{Revisiting Gyekye's criticism and solution}

Gyekye's criticism is predicated on the observation that Menkiti overstates the role of the community in his definition of a person. Gyekye $(1992,108)$ refers to a view held by postindependence leaders and, more specifically, the philosophical elaborations by Menkiti on personhood, as amounting to 'radical communitarianism' (RM). It is interesting to note that Gyekye is under the impression that the idea central to Menkiti's analysis is a metaphysical one (Gyekye 1992, 103). The metaphysical idea under consideration is the idea that a community takes priority over an individual. Gyekye's position is that such a rendering of personhood is 'radical' and it may yield either 'radical or moderate socio-political consequences' (103). Gyekye notes that Menkiti 'succumbed to the temptation' of employing a notion of a person that has implications of a radical political philosophy (104). The idea of personhood as construed in terms of a community taking priority over an individual is said to amount to this radical socio-political stance: 'Radical communitarianism'

$\ldots$ is a view that gives an exaggerated conception of the community, wherein the community is construed as always prior to the individual and this conception of the community fails to recognize the individuality of the individual and the rights that naturally belong to a human person insofar as a person is essentially autonomous. (108)

For Gyekye, the political consequences of Menkiti's position is a failure to recognise the autonomous nature of a human being that accounts for human dignity and this failure further engenders a lack of recognition for rights that naturally belong to individuals. Gyekye's concerns against Menkiti are informed by his prior commitment to the centrality of rights to any robust political polity. Gyekye's position is that Menkiti's communitarianism must be jettisoned since it fails to recognise the primacy of rights. This high regard for rights informs Gyekye's proposed solution of moderate communitarianism. He articulates his solution, thus: 'The restricted communitarianism offers a more appropriate and adequate account of the self ... in that it addresses the dual features of the self: as a communal being and as an autonomous, self-determining...' (Gyekye 1992, 113). Elsewhere he observes: 
The view seems to represent a clear attempt to come to terms with the natural sociality as well as the individuality of the human person. It requires the recognition of communality and individuality ... I think the most satisfactory way to recognize the claims of both communality and individuality is to ascribe to them the status of equal moral standing. (Gyekye 1997, 41, author's emphasis)

Gyekye's moral-political philosophy operates on the assumption that a correct understanding of personhood is crucial to make progress. It is for this reason that he submits that his theory is grounded on an adequate and appropriate idea of a self. This idea of a self is considered to be useful since it grants equal moral consideration to the demands flowing from an individual and one's from a community. Whereas Menkiti's account presents a normative view of social duties as having priority over individual rights, Gyekye defends a view that conceives of a self as constituted by autonomy and sociality.

As a way to justify why we should take Menkiti's thesis seriously, I begin by offering some critical comments to Gyekye's analysis. It is important to note that Gyekye focuses on what we referred to as Menkiti's understanding of personal identity represented by the idea that a community takes priority over an individual. I observed that this is metaphysical claim about personal identity formation and this idea is not an analysis of human nature in terms of what parts constitute it. Gyekye presumes that this metaphysical idea of a community taking priority over an individual undermines the individual and their rights, but does not quite demonstrate this claim. Also, he does not demonstrate how and why this idea of community taking priority over an individual is related to the whole enterprise of rights, but simply assumes it does. This claim, as I have stated above, is a metaphysical one that merely gives us an account of personal identity. It is not clear in Menkiti's analysis that he thinks this idea is related to rights.

Secondly, it is crucial to note that Gyekye overlooks the normative notion that is crucial to Menkiti's analysis and focuses on an idea that is not the cental focus of his article. More so, he even subjects this idea to a criticism that the idea does not even explicitly anticipate - rights.

It is equally urgent that we note that Gyekye's solution introduces a whole new concept of personhood that is completely absent in African thought. The idea of a 'self' introduced by Gyekye represents an account of philosophical anthropology that is characteristic of a naturalist tradition of rights (Donnelly 1982b). Here, some conception of human nature is understood as a basis for human rights. In other words, some feature in virtue of which some being is considered to be of superlative value, possessor of dignity, is offered as a ground for rights (Donnely 2009, 1). These rights are represented as 'natural' because human nature is their source (Donnelly 1982b, 391). This idea strikes me as a patientcentred notion of a person that Menkiti argues is dominant in the Western tradition (see also, Behrens 2013). ${ }^{5}$

It is crucial to note that Menkiti's metaphysical notion does not identify any capacities that constitute a human being, but rather it is an account that accentuates the community as a crucial frame of reference in the humanisation and formation of personal identity. This idea is not related to rights and is not used by Menkiti to suggest an account of rights; or, the relation is not made clear by Gyekye's criticism. If this analysis is correct then it follows that Gyekye criticises a strawman. And, he imports a natural rights tradition that is absent in an African tradition for making sense of rights; an idea that is also foreign to this axiological tradition (Donnelly 1982b). 
One must note that Gyekye simply assumes that rights are crucial in an African tradition but he does not make a case for the ontology and relevance of rights in African tradition. ${ }^{6}$ And, worse, he does not find a local axiological corpus to push his project of rights; he simply borrows from the naturalist tradition of rights from the West. And, this cultural borrowing is not explained or justified. It is treated as if it is natural and uncontroversial. Gyekye has adumbrated an Akan philosophical anthropology, but he does not appeal to it to ground rights. Instead he draws from Kant's tradition to do so, to lend credence to the view that there is no African corpus to justify or even support this commitment to rights.

To make progress and to rediscover the real African moral-political gem contained in Menkiti's contribution that rights are secondary and duties primary, I proceed to analyse the normative idea of personhood pivotal to Afro-communitarian thought.

\section{Personhood, duties and rights ${ }^{7}$}

There is no doubt that African moral-political thought is generally represented in terms of communitarianism; and this talk of communitarianism should be understood as a normative inquiry into what constitutes a good society (Gyekye 1992, 101; Gyekye 1992, 101; Wiredu 1992, 198-200; Mbigi 2005, 75; Metz 2007, 331; Wiredu 2008, 336-340; Masolo 2010). And, this idea of communitarianism is usually connected to the idea of personhood (Mbigi 2005, 75). For example, Wiredu $(2008,336)$ notes:

However, no thought experiment is going to reveal to us the components of the communalist ethic. ${ }^{8}$ It is therefore of a matter of great interest that some of the basic communalistic values of traditional African society can be read off the traditional conception of personhood.

The insight to be gleaned here is that to understand the normative package contained and entailed by Afro-communitarian thought, we need to visit this normative notion of personhood. Below, I demonstrate that the idea of a person promises a morality of duties. The idea of personhood is generally understood as an 'auto-centric' or 'self-realisation' approach to ethics (van Niekerk 2007, 364). A self-realisation account posits some kind of self-favouritism as a proper goal of morality (van Niekerk 2007). In other words, it proposes the agent's perfection of some facet of her human nature as the sole goal of morality. Commenting on this kind of ethics, Augustine Shutte, one of the first scholars to reflect on African ethics, notes:

(T)he moral life is seen as a process of personal growth. ... Our deepest moral obligation is to become more fully human. And this means entering more and more deeply into community with others. So although the goal is personal fulfilment, selfishness is excluded $(2001,24)$.

Another influential scholar of African ethics, Thad Metz $(2010,83)$ also avers:

The ultimate goal of a person, self, or human in the biological sense should be to become a full person, a real self, or a genuine human being, i.e. to exhibit virtue in a way that not everyone ends up doing (Emphasis in original).

In an article dedicated to exploring various competing interpretations of African ethics, Metz (2010, 331; see also Magesa 1997; Ramose 1999; Bujo 2001) observes that this self-realisation ethics entailed by this idea of personhood 'is probably the dominant understanding of ethics' in an African tradition. So, the idea of personhood entails a moral theory 
that makes it the agent's chief goal to realise her true humanity. And, when we say one is a person, we are making a claim that this particular human being is leading a morally upright life. This morally upright life is generally understood as one characterised by moral excellence or virtue (Menkiti 1984; Behrens 2013).

Above, I have just looked at the one side of this moral theory, I just specified the nature of personhood as a moral term that implies a perfectionist moral model, wherein a moral agent has realised true humanity (Metz 2013; Tshivhase 2013). There is another side to this theory that specifies the means necessary for one to achieve such a moral end (Ibid). African scholars converge on the idea that one can only achieve such a status by communing with others, which also entails relating with others positively. In this light, Shutte notes 'I only become fully human to the extent that I am included in relationships with others' $(2001,24)$. Bujo $(2001,88)$ an influential African theologian, also avers 'acting in solidarity for the construction of the community allows himself to be brought to completion by this same community, so that he can become a person truly'. Dzobo concurs: 'our people therefore conceive human life as a force or power that continuously grows recreates itself and so is characterized by continuous change and growth ...' $(1992,227)$.

What begins to emerge from the above is that perfection is possible only in the context of communion or relationships with others. Bujo informed us that one can only be truly human by the assistance of the community and Dzobo also informs us that Africans think of a human life as available to change and development and the function of morality is to effect such a moral change. But these assertions have not quite told us how one achieves perfection. They merely indicate the importance of relationships in the process of achieving personhood. Metz is more explicit in this regard. He informs us that to '... achieve the state of being a (person) is entirely constituted by relating to others in a certain manner' (Metz 2010, 84 author's emphasis). He further notes that personhood can only be achieved by 'relating positively' with others (84). To relate positively is best explained in terms of purely other-regarding duties. It is for this reason that Desmond Tutu comments thus:

When we want to give high praise to someone we say, 'Yu, u nobuntu'; 'Hey, so-and-so has ubuntu.' Then you are generous, you are hospitable, you are friendly and caring and compassionate. You share what you have. It is to say, 'My humanity is caught up, is inextricably bound up in yours ${ }^{\prime 9}$. $(1999,35)$

The idea of ubuntu refers to a human being who has attained a status of being a person. $A$ human being with ubuntu deserves high praise because of how she has conducted herself. It is crucial to note that Tutu combines the idea of community: 'My humanity is caught up, is inextricably bound up in yours'; with the idea of our duties to others: generosity, kindness, hospitality and so on. It appears that because we are naturally understood to be in relationships with others, these relationships engender particular duties we have to each other. It is important to note that all the moral properties mentioned by Tutu picking out a person are purely relational - generous, friendly, kind and so on.

It is crucial to note that all African scholars mention more or less the same purely otherregarding virtues as those characterising a person (Gyekye 1992; Wiredu 1992; Mokgoro 1998). For example, Gyekye $(1992,109)$ notes that 'the ideal and moral virtues can be said to include generosity, kindness, compassion, benevolence, respect and concern for others'. Wiredu also informs us that one's status of personhood depends on how her 
actions benefit others in the community (1992). So, what emerges here is the idea that selfrealisation is function of communing with others, which is captured in terms of purely other-regarding duties.

Thus, the idea of personhood entails a dialogical morality where our chief moral goal is self-realisation but this goal can only be achieved by us fulfilling our other-regarding duties. It is for this reason that Gyekye informs us that African ethics is an 'other-regarding and capacious morality' $(2004,89)$. If this is true then it should follow that the idea of personhood entails a morality of duties to others. But, what is the scope of the 'others' imagined by this morality of duties?

The morality of duties proffers a universal moral vision that encompasses all humanity. Usually, African philosophers capture the scope of the others targeted by our duties in terms of the idea of the 'common good'. By the 'common good' African scholars do not talk in terms of aggregating the interests as is typical in Utilitarianism, but literally refer to a basket of goods that are necessary for an ordinary or even a flourishing life for each human being (Gyekye 2004). To best express this idea of the common good they usually invoke an allegory of a crocodile with two heads and one stomach (Gyekye 2004; Wiredu 2009). Gyekye's (2010, author's emphasis) comment with regard to this imagery is insightful. He notes:

The part of the motif relevant to moral thought is the single stomach... The common stomach ... indicates that at least the basic interests of all the members of the community are identical. It can therefore be interpreted to be symbolizing ... the good of all the individuals within a society.

The 'other' imagined by a morality of duties is every human being. The idea of the common good represents a conception of a good life salient in African moral-political thought. At the heart of this conception of a good life is the idea that all human beings have some basic needs they share in common. These are needs that are considered crucial for their well-being (Wiredu 2009, 10). ${ }^{10}$ If these needs go unsatisfied life will be brutish and uncompromised. It is for this reason that Gyekye $(2004,90-91)$ informs us that a morality of duties is concerned about 'social living' and he also observes that it is 'related, ultimately, to the basic desires and needs of human beings'. Thus, our otherregarding duties are efficacious in securing the well-being of all as captured by the idea of the common good. We may also here briefly pause to roughly look into how African scholars think about our duties.

It is crucial to appreciate that African thinkers who take seriously the idea of the morality of duties as entailed by the idea of personhood do not seem to take seriously the idea of 'options' as often defended by deontological accounts (MacNaughton and Rawling 2006). The idea of 'options' refers to a line that separates moral actions that are permissible/obligatory from those that are beyond the call of duty. Those who take options seriously seem to believe that morality is in some sense limited, it leaves room for us to pursue other things other than morality (Wolf 1992). African scholars usually do not take seriously the idea of the so-called supererogation - that there are no duties that are beyond the call of duty. If morality is about promoting the well-being of all, we have a duty to do so (Cobbah 1987; Gyekye 2010). ${ }^{11}$ I hope it is also clear that here we cannot sacrifice one for the sake of the greater good since this morality is not aggregating - it is focused on securing the well-being of each and every individual. 
The above analysis is suggestive of why duties and rights will tend to clash. To talk of rights is to talk of entitlements that engender duties to a right-holder (Donnely 2009). Rights as entitlements are prior and distinct from duties (Feinberg 1970). To have a right is to be empowered to make claims, assertions and demands that one's duties be fulfilled (Feinberg 1970). Rights are an expression of forms of social living that express respect for a human beings' dignity (Donnely 2009). Thus, the direction of duties engendered by rights is right-holders directed. What makes rights special in the modern moralpolitical thought?

The specialness of rights is a function of their normative force, their peremptory nature (Wenar 2015). The moral authority of rights is usually captured by a metaphor that they have a trumping function (Dworkin 1977, 90). To say that rights are 'trumps' is to assert that under normal circumstances they supersede other social goals (whatever these may be) in a situation where there is a clash (Donnelly 1982a, 2009). The trumping property of rights indicates that they usually take priority over other moral considerations like global utility.

It is this normative force usually associated with rights that does not have a place in African moral thought. The duty for one to realise their true humanity takes central stage in African moral thought and this duty is essentially connected to promotion of the well-being of other human beings. If rights would take central place in African thought, this would threaten the very possibility of individuals attaining a status of personhood that entirely depends on them prioritising the social goal of securing the well-being of all. Rights focus on duties owed to the subject, the right-holder. Whereas, the very prospect and possibility of attaining personhood is essentially connected to purely otherregarding duties to secure their well-being of all. The social goal of securing the wellbeing of all takes priority in this moral theory because it is at the heart of realising a life befitting a human being - personhood.

Put simply, to be a good human being I am required to exercise my duties to others. The best way to focus on what is morally best for me as an agent is to focus on bettering the humanity of others. Whereas, rights in a very crucial way engenders duties that focus on me as a moral patient. It is for this reason that Gyekye $(2004,92)$ though he is not necessarily opposed to rights, notes:

... an obsessive and a belligerent preoccupation with our individual rights can lead to egoism and the concern for our own individual welfare, to the disregard of the needs and welfare of others. Such a moral outlook subverts the notion of community, and, consequently of a shared humanity.

Being aware of the dangers fraught with being obsessed with rights, Gyekye understands that a morality of duties prioritises the notion of community, in a moral sense, that the only way to realise our moral ideal to lead a truly human life is by relating positively with others. And, he links this idea to the fact of our shared humanity, the idea that there are basic commonalities among human beings, and in a moral context, their shared basic needs for well-being. The morality of duties charges us to discharge duties in a context wherein we are caught up with others in relationships (Tutu 1999). It is a duty, not merely a favour or charity, to respond to basic needs and desires of others to ensure that they have the basic conditions befitting a human life, their well-being. 
The danger with rights, he observes, is that they tend to focus on making claims about the well-being of an individual as a right-holder. Each person is left to their own way and their well-being is made their own problem - the idea of negative freedom. It is here that this idea of rights is said to subvert the idea of our purely other-regarding duties to secure the well-being of others; whereas rights talk about duties that are oriented to their holder.

It is for this very reason of the fundamental clash of rights being self-oriented and duties being other-oriented that Gyekye's attempt to marry the idea of community and individuality in his moderate communitarianism will always fail (Oyowe 2014). Gyekye, after vigorously arguing for the urgency, primacy and relevance of rights in Afro-communitarian, he makes this submission about rights:

... that all this said, however, it must be granted that moderate communitarianism cannot be expected to be obsessed with rights. The reason, which is not far to seek, derives from the logic of the communitarian theory itself: it assumes a great concern for values, for the good of the wider society as such. The communitarian society, perhaps like any other type of human society, deeply cherishes the social values of peace, harmony, stability, solidarity, and mutual reciprocities and sympathies. $(1997,65)$

Gyekye's moderate communitarianism fails because of the clashing axiological means employed by a system of rights and one of duties to secure a life of dignity. In a system of rights, it is left largely in individual's shoulders to settle issues of her own well-being; and, in a communitarian setting it is a function of our communion as human beings to assist each other as a moral requirement. This requirement to secure the well-being of all is well captured by Gyekye above when he reminds us that a communitarian logic 'assumes a great concern for values, for the good of the wider society as such'. It is this good of a wider society that takes priority. It is for this reason that ultimately rights will be sacrificed when they clash with duties to promote and secure the well-being of all.

This tension is further evidenced by political systems of governance and policy decision-making envisaged by African scholars by emphasising consensus-based rather than majoritarian-based form of democracy (Gyekye, 1992; Wiredu 1996). Consensus democracy aims to substantively represent the interests all and to avoid a creation of minorities like a majority system does (Wiredu 1996). This tension is also indicated by the how land in traditional African societies was usually owned communally for the benefit of all rather than privately owned (Magesa 1997). The orientation in African thought is securing the interests of all by cooperation whereas the rights orientation emphasises negative freedom as represented by autonomy (Wingo 2009) .

\section{Conclusion}

This article explored the relationship between personhood and rights. Distancing myself from a naturalist understanding of personhood as is typical in Western moral-political philosophy and in the works of an influential African philosopher Gyekye, who defends moderate communitarianism; I unfolded the value system of Afro-communitarianism in light of a salient moral notion of personhood. I ultimately argued that this notion offers us a morality of duties targeting to secure the well-being of all. It is this high moral ideal of securing the well-being of all human beings, I argued, that tends to relegate rights to a secondary status. I am aware that this analysis of personhood and rights is rough and cursory, I 
believe, however, it has given us a sense of why rights cannot take priority in this axiological system.

\section{Notes}

1. I am not aware of a defense of such a position in the literature.

2. MacIntyre (2003) refers to rights as an invention of the enlightenment moral project. He likens them to the medieval belief in witchcraft or unicorns.

3. Darwall $(1977,33)$ refers to it as 'recognition respect', where some entity usually human beings are respected merely because they are recognized to possess moral-ontological feature or even a capacity that marks them out as morally significant.

4. For a detailed comparison of these two normative notions of a 'person' (see Behrens 2013).

5. It is something like this naturalist approach to personhood that Menkiti contrasts his notion against. He observes that this idea is Western and it is a 'minimalist' understanding of a person as it relies on some psychological basis of a person (Menkiti 1984, 174).

6. I am not aware of any African scholar who makes a case for the ontology of rights and justifies them. They are taken to be self-evident.

7. The reader will see below I also draw quite heavily on Gyekye to elaborate on a morality of duties. I wish to allay the concerns this may raise. It is to be noted that that only in his earlier works does Gyekye $(1992,1997)$ defend moderate communitarian, where rights are thought to be equal with duties. In his latter political philosophy, Gyekye $(2004,2010)$ he defends a morality of duties that sees duties as taking priority over rights. It is in this latter political philosophy, I will be drawing. It is crucial to note that many African scholars are fixated with Gyekye's earlier political ideas and they largely ignore his latter political ideas.

8. Here, Wiredu uses the idea of communalist and communitarian somewhat interchangeably to refer to how African organized society (see Wiredu 2008, 335).

9. To say one has 'ubuntu' is one and the same thing to say they are persons. To have Ubuntu means one has develop moral virtues befitting a human being (Shutte 2001, 14).

10. African scholars are not clear about what they have in mind when they use the idea of 'wellbeing'. And, we need have a clear understanding of this term to understand the account developed here.

11. The objection that this (rejection of options) will render morality to be overly demanding does not quite appear to emerge here. African scholars think the fact that one has project and activities pertain to her is not a properly moral issue and one surely is naturally expected to pursue them. But, morality proper is concerned about social living (see Gyekye 2004, 2010).

\section{Disclosure statement}

No potential conflict of interest was reported by the authors.

\section{References}

Ake, C. 1987. "The African Context of Human Rights." Africa Today 34: 5-12.

Behrens, K. 2013. "Two 'Normative' Conceptions of Personhood." Quest 25: 103-118.

Biko, S. 2004. Some African Cultural Concepts. I Write What I Like. Johannesburg: Picador Africa.

Bujo, B. 2001. Foundations of an African Ethic: Beyond the Universal Claims of Western Morality. New York: The Crossroad.

Cobbah, J. 1987. "African Values and the Human Rights: An African Perspective." Human Rights Quarterly 9: 309-331.

Darwall, S. 1977. "Two Kinds of Respect." Ethics 80: 36-49.

Deng, F. 2004. "Human Rights in the African Context." In Companion to African Philosophy, edited by K. Wiredu, 499-508. Oxford: Blackwell. 
Donnely, J. 2009. Human Dignity and Human Rights. Denver: Josef Korbel School of International Studies.

Donnelly, J. 1982a. "Human Rights as Natural Rights." Human Rights Quarterly 4: 391-405.

Donnelly, J. 1982b. "Human Rights and Human Dignity: An Analytic Critique of Non-Western Conceptions of Human Right." The American Political Science Review 76: 303-316.

Dworkin, R. 1977. Taking Rights Seriously. Cambridge: Harvard University Press.

Dzobo, K. 1992. "Values in a Changing Society: Man, Ancestors and God." In Person and Community: Ghanaian Philosophical Studies, 1, edited by K. Gyekye and K. Wiredu, 223-242. Washington, DC: Council for Research in Values and Philosophy.

Famanikwa, J. 2010. "How Moderate is Kwame Gyekye's Moderate Communitarianism?" Thought and Practice: A Journal of the Philosophical Association of Kenya 2: 65-77.

Feinberg, J. 1970. "The Nature and Value of Rights." The Journal of Value Inquiry 4: 243-457.

Gyekye, K. 1992. "Person and Community in African Thought." In Person and Community: Ghanaian Philosophical Studies, 1, edited by K. Gyekye and K. Wiredu, 101-122. Washington, DC: Council for Research in Values and Philosophy.

Gyekye, K. 1997. Tradition and Modernity: Philosophical Reflections on the African Experience. New York: Oxford University Press.

Gyekye, K. 2004. Beyond Cultures: Perceiving a Common Humanity, Ghanaian Philosophical Studies. Accra: The Ghana Academy of Arts and Sciences.

Gyekye, K. 2010. "African Ethics." In The Stanford Encyclopaedia of Philosophy, edited by E. D. Zalta. Accessed January 16, 2013. http://plato.stanford.edu/archives/fall2011/entries/african-ethics.

Ikuenobe, P. 2006. "The Idea of Personhood in Chinua Achebe's Things Fall Apart." Philosophia Africana 9: 117-131.

Kaphagawani, D. 2004. "African Conceptions of a Person: A Critical Surve." In Companion to African Philosophy, edited by K. Wiredu, 332-442. Oxford: Blackwell.

Louw, D. 2004. Ubuntu and the Challenges of Multiculturalism in Post-Apartheid South Africa. Utrecht: Centre for Southern Africa.

Maclntyre, A. 2003. After Virtue. Notre Dame: University of Notre Dame Press.

MacNaughton, D., and P. Rawling. 2006. "Deontology." In Oxford Handbook of Ethical Theory, edited by D. Copp, 425-458. Oxford: Oxford Press.

Magesa, L. 1997. African Religion: The Moral Traditions of Abundant Life. New York: Orbis Books.

Masolo, D. A. 2010. Self and Community in a Changing World. Bloomington: Indiana University Press.

Matolino, B. 2009. "Radicals versus Moderates: A Critique of Gyekye's Moderate Communitarianism." South African Journal of Philosophy 28: 160-170.

Mbigi, L. 2005. The Spirit of African Leadership. Randburg: Knowers.

Mbiti, J. 1969. African Religion and Philosophy. London: Heinemann.

Menkiti, I. 1984. "Person and Community in African Traditional Thought." In African Philosophy: An Introduction, edited by R. A. Wright, 171-181. Lanham: University Press of America.

Menkiti, I. 2004. "On the Normative Conception of a Perso." In Companion to African Philosophy, edited by K. Wiredu, 324-331. Oxford: Blackwell.

Metz, T. 2007. "Toward an African Moral Theory." The Journal of Political Philosophy 15: 321-341.

Metz, T. 2010. "Human Dignity, Capital Punishment and an African Moral Theory: Toward a New Philosophy of Human Rights." Journal of Human Rights 9: 81-99.

Metz, T. 2011. "Ubuntu as a Moral Theory and Human Rights in South Africa." African Human Rights Journal 11: 532-559.

Metz, T. 2012. "An African theory of moral status: A relational alternative to individualism and holism." Ethical Theory and Moral Practice: An International Forum 14: 387-402.

Metz, T. 2013. "Two Conceptions of African Ethics in the Work of D A Masolo." Quest 25: 7-15.

Mokgoro, Y. 1998. "Ubuntu and the Law in South Africa." Potchefstroom Electronic Law Journal 1: $1-11$.

Molefe, M. 2016. "Revisiting the Debate between Gyekye-Menkiti: Who is a Radical Communitarian." Theoria 63: 37-54.

van Niekerk, J. 2007. "In Defence of an Autocentric Account of Ubuntu." South African Journal of Philosophy 26: 364-368. 
Oyowe, A. 2014. "An African Conception of Human Rights? Comments on the Challenges of Relativism." Human Rights Review 15: 329-347.

Ramose, M. 1999. African Philosophy Through Ubuntu. Harare: Mond Books.

Shutte, A. 2001. Ubuntu: An Ethic for a New South Africa. Pietermaritzburg: Cluster.

Toscano, M. 2011. "Human Dignity as High Moral Status." The Ethics Forum 6: 4-25.

Tshivhase, M. 2013. "Personhood: Social Approval or a Unique Identity?" Quest: An African Journal of Philosophy 25: 119-140.

Tutu, D. 1999. No Future Without Forgiveness. New York: Random House.

Wenar, L. 2015. "Rights." In The Stanford Encyclopedia of Philosophy, edited by E. D. Zalta. Accessed June 5, 2016. http://plato.stanford.edu/archives/fall2015/entries/rights/

Wingo, A. 2009. "The Odyssey of Human Rights: A Reply to Souleymane Bachier Dagne." Transition 102: 120-138.

Wiredu, K. 1992. "Moral Foundations of an African Culture." In Person and Community: Ghanaian Philosophical Studies, 1, edited by K. Wiredu and K. Gyekye, 192-206. Washington, DC: The Council for Research in Values and Philosophy.

Wiredu, K. 1996. Cultural Universals and Particulars: An African Perspective. Indianapolis: Indiana University Press.

Wiredu, K. 2009. "An Oral Philosophy of Personhood: Comments on Philosophy and Orality." Research in African Literatures 40: 8-8.

Wiredu, K. 2008. "Social Philosophy in Postcolonial Africa: Some Preliminaries Concerning Communalism and Communitarianism." South African Journal of Philosophy 27: 332-339.

Wiredu, K. 2009. "An Oral Philosophy of Personhood: Comments on Philosophy and Orality." Research in African Literatures 40: 8-18.

Wolf, S. 1992. "Morality and Partiality." Philosophical Perspectives 6: 243-259. 